\title{
In vitro antioxidant potential of dicliptera roxburghiana
}

\author{
Bushra Ahmad ${ }^{1}$, Muhammad Rashid Khan ${ }^{1 *}$, Naseer Ali Shah and Rahmat Ali Khan²
}

\begin{abstract}
Background: Stress caused by free radicals accumulation result into many hazardous diseases. A number of investigations are focusing to find out the plant oriented natural antioxidant moieties. The basic aim of this research was to investigate the antioxidant potential, total Phenolic and flavonoids contents and photochemical screening of the crude methanol extract and its derived various fractions Dicliptera roxburghiana of Acanthaceae family.

Methods: Crude methanol extract of aerial parts of Dicliptera roxburghiana (DRME) was partitioned in to $n$-hexane (DRHF), chloroform (DRCF), ethyl acetate (DREF), $n$-butanol (DRBF) and the remaining soluble portion as residual aqueous fraction (DRAF). We evaluated the antioxidant activities of the extract and various fractions through different analytical methods such as DPPH, superoxide anion, ABTS, $\mathrm{H}_{2} \mathrm{O}_{2}$, hydroxyl radical and phosphomolybdate radical inhibition. In vitro lipid peroxidation and reducing power of the plant was also analyzed. Total flavonoid and phenolic contents of the extract and all fractions were also quantified. Plant was also subjected for preliminary phytochemical screening to confirm the presence or absence of various constituents in the plant.

Results: Phytochemical screening confirmed the presence of flavonoids, phenolics, tannins, alkaloids, saponins, terpenoids and coumarines. Quantitative analysis revealed the maximum amount of total phenolic and flavonoid contents in DRME while lowest in DRHF. Methanol extract, DREF, DRCF and DRBF exhibited promising antioxidant potential for DPPH, ABTS, $\mathrm{H}_{2} \mathrm{O}_{2}$, phosphomolybdate, superoxide anion and hydroxyl radical scavenging capabilities, while these were not appreciable for DRHF and DRAF. All fractions except DRHF and DRAF possess strong reducing power ability and showed appreciable lipid peroxidation inhibition.
\end{abstract}

Conclusion: These research investigations revealed that Dicliptera roxburghiana is a potent source of natural antioxidants. Hence the plant can be used for management of different stress and anxiety related ailments.

Keywords: Dicliptera roxburghiana, Lipid peroxidation, Total flavonoids, Antioxidants

\section{Background}

Biochemical and physiological course of action, taking place nearly in all type of the living cells, result into production of harmful free radicals and reactive oxygen species [1]. These free radicals and reactive oxygen species damage the bimolecular moieties such as DNA, proteins and lipids; ultimately become leading source of different chronic serious ailments like cancer, aging, diabetes, atherosclerosis etc. [2]. To overcome this hazard nature has provided us a defense shield in the form of dietary antioxidants from plants. Medicinal plants play a crucial role

\footnotetext{
* Correspondence: mrkanqau@yahoo.com

${ }^{1}$ Department of Biochemistry, Faculty of Biological Sciences,

Quaid-i-Azam University, Islamabad 45320, Pakistan

Full list of author information is available at the end of the article
}

for the management of various ailments [3-8]. Plants are richly supplied with vitamins, flavonoids, coumarins, phenolics, terpenoids, tannins and alkaloids etc. that are strong antioxidants [9]. Hence, medicinal plants contain many key compounds that can be used for the management of oxidative stress induced diseases $[10,11]$. The positive outcome by intake of antioxidant moieties of plant origin have been publicized in a number of investigational and epidemiological studies [12,13].

Dicliptera roxburghiana, belongs to the family Acanthaceae, is a perennial herb with $2-7 \mathrm{dm}$ long stems. Leaves are green and are slightly paler on lower surface with 1-3.5 cm long petioles. Flowers are arranged in axillary cymes and all bracts are short-villous 
especially along the margins, calyx lobes are of unequal size, 5-7 mm long; color of corolla varies from rose to purple. Capsules are 6-7 $\mathrm{mm}$ long [14]. Saturated fatty acids (C-15 to C-31) and flavonoids (apigenin, kaempferol, luteolin and apigenin-7-O-glucoside) were isolated and identified from Dicliptera roxburghiana [15]. Powder of the plant is used as general tonic [16], for wound healing [17] and is non toxic [18]. As there is no published data for the antioxidant potential of $D$. roxburghiana, so this study was designed to investigate the antioxidant potential of the plant along with its total phenolic and flavonoid contents.

\section{Methods}

\section{Plant material}

Dicliptera roxburghiana was collected at maturity from the campus of Quaid-i-Azam University in April 2012. Identification of plant was validated by Dr. Mir Ajab Khan, Department of Plant Sciences Quaid-i-Azam University, Islamabad and a voucher specimen (accession\#125521) was submitted in the Herbarium of Pakistan situated at Quaid-i-Azam University Islamabad, Pakistan. It was shade dried $\left(28 \pm 2^{\circ} \mathrm{C}\right)$ and leaves were coarsely pulverized to obtain dry powder in Willy Mill to 60-mesh size. Powder was stored at room temperature for further analysis.

\section{Preparation of methanol extract}

Methanol was selected as extraction solvent due to its ability to dissolve a vast variety of compounds in it. Plant powder $(2.0 \mathrm{~kg})$ was soaked in crude methanol $(4.0 \mathrm{~L})$ in large container and was regularly shaken for five days at room temperature $\left(28 \pm 2^{\circ} \mathrm{C}\right)$. Than it was filtered through Whatmann filter paper No. 45 and the reextraction of the residue was repeated twice. Filtrate was dried under rotary vacuum evaporator (Panchun Scientific Co, Kaohsiung, Taiwan) at $40^{\circ} \mathrm{C}$ to yield concentrated dry extract. Methanol extract of plant D. roxburghiana (DRME) yielded $200 \mathrm{~g}$ dark green viscous material (10\%) that was stored at $4^{\circ} \mathrm{C}$ for further investigations.

\section{Preparation of fractions}

Further fractions were made by suspending $4 \mathrm{~g}$ of crude methanol extract in distilled water $(200 \mathrm{ml})$. This solution was then successively partitioned with $n$-hexane, chloroform, ethyle acetate and $n$-butanol in separating funnel and yielded DRHF (4.7\%), DRCF (4.2\%), DREF (5.8\%), DRBF (6.7\%) respectively with residual aqueous fraction, DRAF (8.6\%). Each fraction was collected, dried and stored at $4^{\circ} \mathrm{C}$ [19].

\section{Chemicals}

All the chemicals used in these assays were of high polarity (99\%). Ascorbic acid, gallic acid, rutin, Folin-Ciocalteu's phenol reagent, $\mathrm{AlCl}_{3} \cdot 6 \mathrm{H}_{2} \mathrm{O}$, 2,2-Diphenyl-1-Picrylhydrazyl (DPPH), 2,2- azino-bis (3-ethylbanzthiazoline-6- sulphonic acid (ABTS), potassium oxidopersulphate, ammonium molybdate, phenazine methosulphate (PMS), nitroblue tetrazolium (NBT), ferric chloride, potassium chloride, trichloroacetic acid (TCA), thiobarbituric acid (TBA), potassium ferricynide, Mayer's reagent, $\mathrm{FeCl}_{3}$ were purchased from Sigma Co. (St. Louis, MO, USA). $\mathrm{H}_{2} \mathrm{SO}_{4}, 2$ deoxyribose riboflavin, $\mathrm{Na}_{2} \mathrm{CO}_{3}, \mathrm{NaOH}, \mathrm{NaNO}_{2}, \mathrm{H}_{2} \mathrm{O}_{2}$ were purchased from Wako Co. (Osaka, Japan). All analytical grade solvents e.g. $n$-hexane, chloroform, ethyl acetate and $n$-butanol were used with $99.8 \%$ purity level and were obtained from Merck Co. (Darmstadt, Germany). Ultrapure TM water purification system (Lotum Co., Ltd., Taipei, Taiwan) was used to get deionized distilled water.

\section{Quantitative analysis \\ Total polyphenolic contents quantification}

Total polyphenolic contents were measured by spectrophotometric method according to Bursal and Gulcin [20]. Extract/fraction $(1 \mathrm{ml})$ was mixed with $9 \mathrm{ml}$ of distilled water. Folin-Ciocalteu's phenol reagent $(1 \mathrm{ml})$ was put in to the mixture followed by $7 \% \mathrm{Na}_{2} \mathrm{CO}_{3}$ solution $(10 \mathrm{ml})$ and was shaken. The mixture was diluted 25 times with deionized distilled water. After $90 \mathrm{~min}$ absorbance was measured at $750 \mathrm{~nm}$. Gallic acid $(0-100 \mathrm{mg} / \mathrm{ml})$ was used for standard curve. The measured total polyphenolics were expressed as mg Gallic acid equivalents (GAE) per $g$ of dried sample.

\section{Total flavonoids contents quantification}

Total flavonoid contents were analyzed by following the Protocol of Park et al. [21]. For this purpose $0.3 \mathrm{ml}$ extract, $3.4 \mathrm{ml}$ methanol (30\%), $0.15 \mathrm{ml}$ of $\mathrm{NaNO}_{2}(0.5 \mathrm{M})$ and $0.1 \mathrm{ml}$ of $\mathrm{AlCl}_{3} \cdot 6 \mathrm{H}_{2} \mathrm{O}(0.3 \mathrm{M})$ were added in a test tube and mixed well. After $6 \mathrm{~min} 1 \mathrm{ml} \mathrm{NaOH}(1 \mathrm{M})$ was put into the mixture. The absorbance was checked at $506 \mathrm{~nm}$. Rutin solution $(0-100 \mathrm{mg} / \mathrm{L})$ was used to form standard curve of total flavonoids. Total flavonoids were measured as $\mathrm{mg}$ of rutin equivalent/g of dried sample.

\section{Investigation of antioxidant potential}

Each fraction (1 mg) was dissolved in $1 \mathrm{ml}$ methanol to form stock solutions. Then further dilutions $(20,50$, $100,150,200$ and $250 \mu \mathrm{g} / \mathrm{ml}$ ) of each fraction were formed.

\section{Diphenyl-1-Picrylhydrazyl (DPPH) assay}

$\mathrm{DPPH}$ assay was performed according to the procedure of Brand-Willium et al. [22]. For this purpose $0.1 \mathrm{M}$ DPPH (1, 1- diphenyl-2-picrylhydrazyl) solution was made in methanol and absorbance of the solution was adjusted at 0.95 at $515 \mathrm{~nm}$. Sample $(100 \mu \mathrm{l})$ was mixed with $1 \mathrm{ml}$ $\mathrm{DPPH}$ solution and incubated at $37^{\circ} \mathrm{C}$ for $30 \mathrm{~min}$. Methanol was used as control. After $30 \mathrm{~min}$ absorbance was noted at $515 \mathrm{~nm}$. Ascorbic acid was used as standard. 
DPPH scavenging activity was calculated according to following formula and $\mathrm{IC}_{50}$ was calculated.

Inhibition $(\%)=[$ (Absorbance of control - Absorbance of sample) / Absorbance of control] $\times 100$

\section{Azino-bis (3-ethylbanzthiazoline-6- sulphonic acid (ABTS) scavenging activity}

Protocol of Re et al. [23] was adopted for evaluation of ABTS scavenging activity. ABTS solution $(7 \mathrm{mM})$ was mixed with potassium oxidopersulphate $(2.45 \mathrm{mM})$ solution and was placed in the dark for $12-16 \mathrm{~h}$ to get a dark colored ABTS working solution. The solution was diluted with $50 \%$ methanol and absorbance was adjusted at $0.7( \pm 0.02)$ at $734 \mathrm{~nm}$. Sample $(100 \mu \mathrm{l})$ was mixed with $1 \mathrm{ml}$ of ABTS working solution and decrease in absorbance was read 1 min after adding the sample and then up to $6 \mathrm{~min}$. Percentage inhibition was calculated according to following formula

Inhibition $(\%)=[$ (Absorbance of control - Absorbance of sample)/ Absorbance of control] $\times 100$.

\section{Phosphomolybdate assay}

This assay was performed according to the procedure of Umamaheswari and Chatterjee [24]. Working reagent was formed by mixing $0.6 \mathrm{M} \mathrm{H}_{2} \mathrm{SO}_{4}, 28 \mathrm{mM}$ sodium phosphate and $4 \mathrm{mM}$ ammonium molybdate. Sample $(100 \mu \mathrm{l})$ was mixed with $1 \mathrm{ml}$ working reagent to form mixture which was placed in water bath for $90 \mathrm{~min}$ at $95^{\circ} \mathrm{C}$. After cooling the mixture at room temperature absorbance was read at $765 \mathrm{~nm}$ against a blank. Ascorbic acid was run as standard. Antioxidant activity was determined according to following formula:

Antioxidant effect $(\%)=[$ (control absorbance-sample absorbance) / (control absorbance) $] \times 100$.

\section{Superoxide anion radical scavenging assay}

Protocol of Beauchamp and Fridovich [25] was followed to investigate the above mentioned assay. Phosphate buffer $0.5 \mathrm{ml}$ (50 mM, pH 7.6), $0.3 \mathrm{ml}$ riboflavin (50 mM), $0.25 \mathrm{ml}$ PMS (20 mM) and $0.1 \mathrm{ml} \mathrm{NBT}$ $(0.5 \mathrm{mM})$ were mixed to make reaction solution. Sample $(100 \mu \mathrm{l})$ was mixed with $1 \mathrm{ml}$ reaction solution and mixture was placed under fluorescent lamp for $20 \mathrm{~min}$. Absorbance was measured at $560 \mathrm{~nm}$. Ascorbic acid was taken as standard. The percent inhibition of superoxide anion generation was calculated by following formula:

Scavenging activity $(\%)=(1-$ absorbance of sample / absorbance of control) $\times 100$.

\section{Hydrogen peroxide scavenging activity}

This activity was assessed by following the procedure of Ruch et al. [26]. Hydrogen peroxide solution (2 mM) was formed in phosphate buffer (50 mM, pH 7.4). Sample $(100 \mu \mathrm{l})$ was mixed with $400 \mu \mathrm{l}$ phosphate buffer and $600 \mu \mathrm{l}$ of $\mathrm{H}_{2} \mathrm{O}_{2}$. Reaction solution was vortexed and incubated for $10 \mathrm{~min}$ at room temperature and then absorbance was analyzed at $230 \mathrm{~nm} . \mathrm{H}_{2} \mathrm{O}_{2}$ scavenging activity was calculated by following formula:

Hydrogen peroxide scavenging activity $=(1-$ absorbance of sample/absorbance of control) $\times 100$.

\section{Hydroxyl radical scavenging assay}

This activity was determined by following the protocol of Halliwell and Gutteridge [27]. Reaction solution consisted of 2- deoxyribose $500 \mathrm{ml}(2.8 \mathrm{mM})$ in phosphate buffer (50 mM, pH 7.4), $200 \mathrm{ml}$ premixed ferric chloride (100 mM) solution (1:1; v/v), $100 \mathrm{ml} \mathrm{H}_{2} \mathrm{O}_{2}(200 \mathrm{mM})$ and extract solution $(100 \mathrm{ml})$. Ascorbate $100 \mathrm{ml}(300 \mathrm{mM})$ was added to the reaction solution and incubated for $1 \mathrm{~h}$ at $37^{\circ} \mathrm{C}$. TBA solution $1 \mathrm{ml}(1 \%$; w/v in $50 \mathrm{mM} \mathrm{NaOH})$ and $1 \mathrm{ml}$ TCA (2.8\%; w/v aqueous solution) were added to the reaction solution. Reaction solution was heated in boiling water bath for $15 \mathrm{~min}$ and then was allowed to cool. Absorbance was noted at $532 \mathrm{~nm}$ and scavenging activity of hydroxyl radical was calculated as follow:

Scavenging activity $(\%)=(1-$ absorbance of sample / absorbance of control) $\times 100$.

\section{In vitro lipid peroxidation assay at chicken liver}

A healthy chicken was killed; liver was removed and was washed with $0.9 \%$ saline. The fresh liver tissue was homogenized in buffer, $\mathrm{pH} 7.4(0.174 \mathrm{M} \mathrm{KCl}$ and $0.25 \mathrm{mM}$ Tris $\mathrm{HCl}$ ) Hunter et al. [28]. The study procedure for the animal care and experimentation was permitted by Ethical Committee of Quaid-i-Azam University Islamabad.

Lipid peroxidation assay was performed by following the protocol of Iqbal et al. [29]. Phosphate buffer $0.58 \mathrm{ml}$ (0.1 M; PH 7.4), $200 \mu$ l sample, $200 \mu$ l liver homogenate and $20 \mu \mathrm{l}$ ferric chloride $(100 \mathrm{mM})$ were combined to form mixture which was placed in a shaking water bath for $1 \mathrm{~h}$ at $37^{\circ} \mathrm{C}$. Reaction was terminated by adding $1 \mathrm{ml}$ TCA (10\%). TBA $1 \mathrm{ml}(0.67 \%)$ was added to all the tubes which were placed in boiling water bath for $20 \mathrm{~min}$. Then test tubes were shifted to crushed ice bath and were centrifuged at $2500 \times \mathrm{g}$ for $10 \mathrm{~min}$. Absorbance of the supernatant was checked at $535 \mathrm{~nm}$ and was calculated as $\mathrm{nM}$ $\mathrm{MDA} / \mathrm{min} / \mathrm{mg}$ tissue by using molar extinction coefficient of $1.56 \times 10^{5} / \mathrm{M} / \mathrm{cm}$. 


\section{Reducing power assay}

Reducing power assay was investigated by following the protocol of Gulcin et al. [30]. Phosphate buffer $2 \mathrm{ml}$ (0.2 M, pH 6.6), sample $2 \mathrm{ml}$, and $2 \mathrm{ml}$ potassium ferricynide $(10 \mathrm{mg} / \mathrm{ml})$ were mixed and were incubated for $20 \mathrm{~min}$ at $50^{\circ} \mathrm{C}$. After incubation $2 \mathrm{ml} \mathrm{TCA}(100 \mathrm{mg} / \mathrm{ml})$ was added into the mixture. This mixture $(2 \mathrm{ml})$ was mixed with $2 \mathrm{ml}$ distilled water and $0.4 \mathrm{ml}$ ferric chloride $(0.1 \% ; \mathrm{w} / \mathrm{v})$ and absorbance was noted at $700 \mathrm{~nm}$ after $10 \mathrm{~min}$. Increase in absorbance was noted that was an indication of strong reducing power capability.

\section{Preliminary phytochemical screening}

Preliminary phytochemical screening of $D$. roxburghiana was done by different qualitative assay procedures to validate the presence or absence of flavonoids, phenolics, coumarines, alkaloids, tannins, saponins, phlobatannins, anthraquinone and terpenoids.

\section{Alkaloid screening}

Alkaloidal screening was done according to the protocol of Farnsworth and Euler [31] with some modifications. Extract $(500 \mathrm{mg})$ was moistened with $\mathrm{Ca}(\mathrm{OH})_{2}$ solution $(40 \%)$ to remove acids, phenolics and tannins. Further extraction was carried out with the chloroform $(10 \mathrm{ml})$ twice and filtrate was concentrated. Aqueous acid solution was added to the concentrated extract to form alkloidal salts which were soluble in aqueous layer and impurities in the organic phase were separated. Aqueous phase was treated with ammonia solution to precipitate the alkloidal salts which were alkaline to litmus paper. Extract was mixed with Dragendroff's reagent. Dark orangish red color determined the presence of alkaloids.

\section{Saponins screening}

Plant saponins were detected according to the procedure of Wall et al. [32]. Blood standardization was done to get red blood cell suspension. One ml extract was added in $10 \mathrm{ml}$ of standardized blood suspension and was kept at room temperature $\left(28 \pm 2^{\circ} \mathrm{C}\right)$ for $5 \mathrm{~min}$. Complete hemolysis of red blood cells was considered an indication of presence of saponins.

\section{Terpenoids screening}

An amount of $5 \mathrm{mg}$ sample was mixed with $5 \mathrm{ml}$ distilled water and $2 \mathrm{ml}$ of chloroform was put into the mixture along with subsequent addition of $3 \mathrm{ml} \mathrm{H}_{2} \mathrm{SO}_{4}$. A reddish brown line was formed that was a sign of presence of terpenoids [33].

\section{Coumarins screening}

Sample $(300 \mathrm{mg})$ was taken in a test tube that was covered with filter paper moistened with $\mathrm{NaOH}(1 \mathrm{~N})$. Test tubes were kept in a boiling water bath for few min.
After that filter paper was analyzed under UV light and presence of coumarins was confirmed as yellow fluorescence [34]. Another confirmatory test was carried out; filter paper was sprayed with phenylboric acid, $\beta$-aminoethyl ester [35] and the presence of coumarins was confirmed.

\section{Flavonoid screening}

Sample $(25 \mathrm{mg})$ was put into $50 \mathrm{ml}$ distilled water and was filtered. $10 \mathrm{ml}$ of filtrate was combined with $5 \mathrm{ml}$ of dilute ammonia solution after that few drops of concentrated $\mathrm{H}_{2} \mathrm{SO}_{4}$ were added. Yellow color was a sign of presence of flavonoids [36].

\section{Tannins screening}

$50 \mathrm{mg}$ sample was put into $20 \mathrm{ml}$ distilled water and was filtered. Few drops of $\mathrm{FeCl}_{3}$ were combined with filtrate and presence of tannins was confirmed by appearance of brownish green color [36]. Filtrate paper was also sprayed with two drops of basic lead acetate solution. Appearance of white precipitate confirmed the presence of tannins [37].

\section{Statistical analysis}

Results are analyzed as mean \pm SD from triplicate observations. In vitro antioxidant assays were analyzed by ANOVA test followed by Tukey'test $(\mathrm{P}<0.05)$ to find out the significant differences among $\mathrm{IC}_{50}$ of different fractions in each assay. Graph Pad prism software was applied to determine the $\mathrm{IC}_{50}$ values.

\section{Results}

\section{Preliminary phytochemical screening}

Preliminary phytochemical screening of all derived fractions of D. roxburghiana demonstrated the presence of flavonoids, phenolics, terpenoids, tannins, alkaloids, saponins and coumarins as shown in Table 1.

Total phenolics and flavonoid contents and extraction yield Extraction yield of the methanol extract and various fractions ranged from $4.2 \pm 3.6 \%$ to10.3 $\pm 1.1 \%$ with an ascending order of $\mathrm{DRCF}<\mathrm{DRHF}<\mathrm{DREF}<\mathrm{DRBF}<\mathrm{DRAF}<$ DRME (Table 2). Maximum yield with methanol extraction determined highest quantities of extractable compounds whereas chloroform extraction yield was very low.

Total phenolic contents of methanol and all other fractions of $D$. roxburghiana varied widely, ranging from $13.5 \pm 0.9 \mathrm{mg}$ to $189.4 \pm 1.1 \mathrm{mg}$ Gallic acid equivalent $/ \mathrm{g}$ dry weight with the reference of standard curve $(\mathrm{Y}=$ $\left.0.004_{X}, r^{2}=0.995\right)$. Total phenolic contents were solvent dependent. Highest phenolics contents were found in methanol extract whereas $n$-hexane fraction reflected small quantity of phenolics. Flavonoid contents also varied widely among different fractions. Methanol extract exhibited highest flavonoid contents whereas DRHF showed small amount, ranging from $235.3 \pm 0.8 \mathrm{mg}$ to $18.7 \pm 1.2 \mathrm{mg}$ 
Table 1 Preliminary phytochemical screening of $D$. roxburghiana

\begin{tabular}{lccccccc}
\hline Extract & Flavonoids & Phenolics & Alkaloids & Tannins & Saponins & Coumarins & Terpenoids \\
\hline DRME & + & + & + & + & + & + & + \\
DRHF & + & - & + & + & + & + & + \\
DRCF & + & + & + & + & + & + & + \\
DREF & + & + & + & + & + & + \\
DRBF & + & + & - & + & + & + \\
DRAF & + & + & + & + & + \\
\hline
\end{tabular}

DRME D. roxburghiana methanol extract, DRHF D. roxburghiana $n$-hexane fraction, DRCF D. roxburghiana chlorofrorm fraction, DREF D. roxburghiana ethyl acetate fraction, DRBF D. roxburghiana $n$-butanol fraction, DRAF D. roxburghiana aqueous fraction.

Rutin equivalent/g dry weight with reference standard curve $\left(Y=0.003_{X}, r^{2}=0.932\right)$ as depicted in Table 2.

\section{In vitro antioxidant potential}

In vitro antioxidant potential of the plant was determined using different analytical assays. All antioxidant assays provide considerable support to antioxidant prospective of plant in comparison with standard ascorbic acid.

\section{DPPH scavenging activity}

Figure 1A describes the DPPH activity of the plant and was found in the following order: DRCF > DRME > DRBF > DREF > DRAF > DRHF. IC $_{50}$ values were $114.27 \pm$ $1.2 \mu \mathrm{g} / \mathrm{ml}, 121.03 \pm 1.5 \mu \mathrm{g} / \mathrm{ml}$ and $124.23 \pm 1.1 \mu \mathrm{g} / \mathrm{ml}$ for DRCF, DRME and DRBF respectively (Table 3). Although antioxidant effects of various extracts were low as compared to standards still they were appreciable. Positive correlations were existed among $\mathrm{DPPH} \mathrm{IC}_{50}$ values of fractions and their total phenolics and flavonoid contents.

\section{Superoxide anion scavenging activity}

Figure $1 \mathrm{~B}$ reflects the superoxide radical quenching capability of various fractions of the plant and was found in the following order: DRME > DRCF > DRBF > DREF > DRAF > DRHF. $\mathrm{IC}_{50}$ values (Table 3 ) varied widely among different fractions and were appreciable for DRME

\begin{tabular}{|c|c|c|c|}
\hline Plant extract & Total phenolics & Total flavonoids & Extraction yield \\
\hline DRME & $189.4 \pm 1.1^{\mathrm{a}}$ & $235.3 \pm 0.8^{\mathrm{a}}$ & $10.3 \pm 1.1^{\mathrm{a}}$ \\
\hline DRHF & $13.5 \pm 0.9^{f}$ & $18.7 \pm 1.2^{d}$ & $4.7 \pm 5.7^{\mathrm{e}}$ \\
\hline DREF & $163.3 \pm 2.1^{c}$ & $213.3 \pm 1.1^{b}$ & $5.8 \pm 4.8^{d}$ \\
\hline DRCF & $179.5 \pm 0.3^{b}$ & $218.7 \pm 1.5^{b}$ & $4.2 \pm 3.6^{\mathrm{e}}$ \\
\hline DRBF & $135.9 \pm 0.4^{d}$ & $203.3 \pm 1.7^{b}$ & $6.7 \pm 0.9^{c}$ \\
\hline DRAF & $82.7 \pm 0.5^{e}$ & $69.4 \pm 0.8^{c}$ & $8.6 \pm 2.5^{b}$ \\
\hline
\end{tabular}

Values are represented as mean $\pm(n=3)$, Different letter $\left({ }^{\text {a-e }}\right)$ represent significance $(P<0.05)$.

DRME D. roxburghiana methanol extract, DRHF D. roxburghiana n-hexane fraction, $D R C F D$. roxburghiana chlorofrorm fraction, DREF D. roxburghiana ethyl acetate fraction, DRBF D. roxburghiana $n$-butanol fraction, DRAF D. roxburghiana aqueous fraction.
$(56.46 \pm 0.3 \mu \mathrm{g} / \mathrm{ml})$ and DRCF $(73.18 \pm 0.4 \mu \mathrm{g} / \mathrm{ml})$. These values were low as compared to standards at the same dose but still were significant.

\section{Hydroxyl radical scavenging activity}

All fractions exhibited a good percentage inhibition as described in Figure $1 \mathrm{C}$ and behave as potent radical scavengers. Methanol extract and DRCF showed strong antioxidant potential against this radical with $\mathrm{IC}_{50}$ values $17.94 \pm 0.1 \mu \mathrm{g} / \mathrm{ml}$ and $23.62 \pm 0.1 \mu \mathrm{g} / \mathrm{ml}$ respectively. $\mathrm{IC}_{50}$ of different fractions was in the following order: DRME $>$ DRCF $>$ DREF $>$ DRBF $>$ DRHF $>$ DRAF.

\section{Phosphomolybdate radical scavenging activity}

Methanol extract showed the highest percentage inhibition with $\mathrm{IC}_{50}$ value $24.18 \pm 0.6 \mu \mathrm{g} / \mathrm{ml}$ when compared with $\mathrm{IC}_{50}$ value $(20.76 \pm 0.3 \mu \mathrm{g} / \mathrm{ml})$ of standard ascorbic acid at the same dose level. Among all fractions $\mathrm{IC}_{50}$ values were significantly different (Table 3 ) and decrease in the following manner: DRME > DRCF > DRBF > DREF $>$ DRAF $>$ DRHF as shown in Figure 1D.

\section{ABTS radical scavenging activity}

ABTS radical scavenging effects were significant $(\mathrm{P}<0.05)$ among all fractions as shown in Table 3 and reflect strong antioxidant potential of the plant. Figure $1 \mathrm{E}$ describes inhibition percentage of methanol and all derived fractions of $D$. roxburghiana. ABTS antiradical activity decreases in the order of: DRCF > DRME > DRBF > DREF, with significantly different $\mathrm{IC}_{50}$ values ranging from $123.75 \pm 0.2$ to $217.79 \pm 0.6 \mu \mathrm{g} / \mathrm{ml}$.

\section{$\mathrm{H}_{2} \mathrm{O}_{2}$ radical scavenging activity}

This radical scavenging activity was also concentration dependent with significant $\mathrm{IC}_{50}(\mathrm{P}<0.05)$ values as described in Table 3. All fractions reflect a good measure of antioxidant activity to scavenge $\mathrm{HO}$ radical (Figure 1F) except DRHF and DRAF. Order of activity decreased in given manner: DRME $>$ DRCF $>$ DREF $>$ DRBF. 

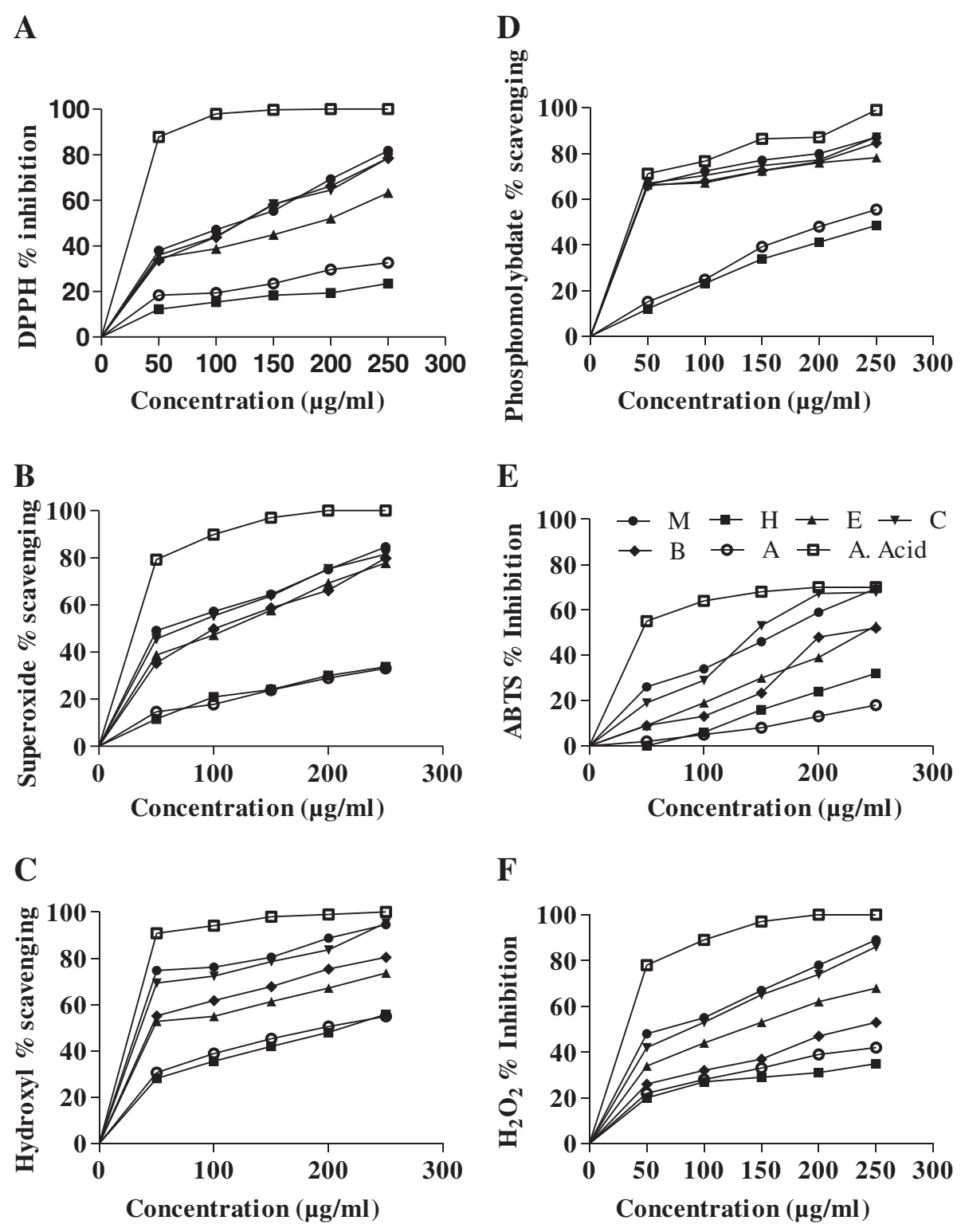

Figure 1 Antioxidant activity of different fractions and methanol extract of $D$. roxburghiana at different concentrations with a mean \pm SD ( $n=3)$ : (A) DPPH radical scavenging activity, (B) Superoxide radical scavenging activity, (C) Hydroxyl radical scavenging activity, (D) Phosphomolybedate radical scavenging activity, (E) ABTS radical scavenging activity and (F) Hydrogen peroxide radical scavenging activity. M: methanol, H: n-hexane, E: ethyl acetate, C: chloroform, B: n-butanol, A: aqueous and A. acid: ascorbic acid.

Correlation between $\mathrm{IC}_{50}$ of antioxidant assays and total phenolic and flavonoid contents

A positive correlation was found for total phenolic contents and radical scavenging assays with significant $R^{2}$ values $\left(R^{2}=0.883,0.8588,0.7154,0.8635\right)$ for $I_{50}$ values of DPPH, superoxide, phosphomolybdate and ABTS radical scavenging activity respectively where as correlation of phenolic contents was weak for $\mathrm{H}_{2} \mathrm{O}_{2}$ and hydroxyl radical scavenging activity with $\mathrm{R}^{2}$ values 0.5158 and 0.5883 respectively (Table 4 ).
For total flavonoid contents a significant correlation $\left(R^{2}=0.9634,0.9632,0.8924,0.9458\right.$ and 0.6608$)$ was found between total flavonoid contents and $\mathrm{IC}_{50}$ values of DDPH, superoxide, phosphomolybdate, ABTS and hydroxyl radical respectively (Table 4).

\section{Lipid peroxidation inhibition}

Figure 2 describes dose concentration curve for the \% inhibition of lipid peroxidation of different plant derived fractions as compared to standard ascorbic acid. It was 
Table 3 Antioxidant effect $\left(\mathrm{IC}_{50}\right)$ of different fraction of $D$. roxburghiana

\begin{tabular}{lcccccc}
\hline $\begin{array}{l}\text { Plant } \\
\text { extract }\end{array}$ & $\begin{array}{c}\text { DPPH radical } \\
\text { scavenging } \\
\text { activity }\end{array}$ & $\begin{array}{c}\text { Superoxide radical } \\
\text { scavenging activity }\end{array}$ & $\begin{array}{c}\text { Phosphomolybdate } \\
\text { scavenging activity }\end{array}$ & $\begin{array}{c}\text { Hydroxyl radical } \\
\text { scavenging activity }\end{array}$ & $\begin{array}{c}\text { ABTS radical } \\
\text { scavenging } \\
\text { activity }\end{array}$ & $\begin{array}{c}\mathbf{H}_{2} \mathrm{O}_{2} \text { radical } \\
\text { scavenging } \\
\text { activity }\end{array}$ \\
\hline DRME & $121.03 \pm 1.5^{\mathrm{b}}$ & $56.46 \pm 0.3^{\mathrm{b}}$ & $24.18 \pm 0.6^{\mathrm{b}}$ & $17.94 \pm 0.1^{\mathrm{b}}$ & $153.78 \pm 0.2^{\mathrm{b}}$ & $77.38 \pm 0.5^{\mathrm{c}}$ \\
DRHF & $>250^{\mathrm{d}}$ & $>250^{\mathrm{e}}$ & $234.57 \pm 0.3^{\mathrm{f}}$ & $46.25 \pm 0.7^{\mathrm{e}}$ & $>250^{\mathrm{e}}$ & $>250^{\mathrm{f}}$ \\
DREF & $195.23 \pm 0.4^{\mathrm{c}}$ & $112.71 \pm 0.6^{\mathrm{d}}$ & $40.73 \pm 0.2^{\mathrm{d}}$ & $32.56 \pm 0.9^{\mathrm{d}}$ & $217.79 \pm 0.6^{\mathrm{d}}$ & $136.61 \pm 0.9^{\mathrm{d}}$ \\
DRCF & $114.27 \pm 1.2^{\mathrm{b}}$ & $73.18 \pm 0.4^{\mathrm{c}}$ & $35.81 \pm 0.4^{\mathrm{c}}$ & $23.62 \pm 0.1^{\mathrm{c}}$ & $123.75 \pm 0.2^{\mathrm{b}}$ & $88.59 \pm 0.3^{\mathrm{c}}$ \\
DRBF & $124.23 \pm 1.1^{\mathrm{b}}$ & $106.24 \pm 0.7^{\mathrm{d}}$ & $36.15 \pm 0.5^{\mathrm{c}}$ & $40.87 \pm 0.5^{\mathrm{e}}$ & $195.87 \pm 0.3^{\mathrm{c}}$ & $205.81 \pm 0.2^{\mathrm{e}}$ \\
DRAF & $>250^{\mathrm{d}}$ & $>250^{\mathrm{e}}$ & $188.26 \pm 0.9^{\mathrm{e}}$ & $67.24 \pm 0.3^{\mathrm{f}}$ & $>250^{\mathrm{e}}$ & $>250^{\mathrm{f}}$ \\
Ascorbic & $14.37 \pm 0.9^{\mathrm{a}}$ & $26.81 \pm 0.4^{\mathrm{a}}$ & $20.76 \pm 0.3^{\mathrm{a}}$ & $6.87 \pm 0.4^{\mathrm{a}}$ & $54.72 \pm 0.3^{\mathrm{a}}$ & $29.18 \pm 0.6^{\mathrm{b}}$ \\
acid & & & & & &
\end{tabular}

Values are represented as mean $\pm(\mathrm{n}=3)$, Different letter $\left({ }^{\mathrm{a}-\mathrm{f}}\right)$ represent significance $(\mathrm{P}<0.05)$. DRME D. roxburghiana methanol extract, DRHF $D$. roxburghiana $n$-hexane fraction, DRCF D. roxburghiana chlorofrorm fraction, DREF D. roxburghiana ethyl acetate fraction, $D R B F D$. roxburghiana $n$-butanol fraction, DRAF D. roxburghiana aqueous fraction.

demonstrated that DRME, DRBF, and DRCF have appreciably reduced the TBARS contents formed during lipid peroxidation.

\section{Reducing power of $D$. roxburghiana}

As reducing power is a significant marker to measure the antioxidant capability so it was determined that increase in reducing power was actually the measure of antioxidant manifestations of the plant. Reducing power was also concentration dependant. Reducing power activity was not significant at low doses as compared to ascorbic acid but gradual increasing concentrations of fractions increased the reducing power capability of DRME, DRCF, DRBF and DREF significantly as demonstrated by Figure 3 .

\section{Discussion}

Free radicals play a key role in pathological manifestations. These phyto-originated constituents perform their role either by quenching the ROS or by acting as a defense shield to protect the antioxidant defense mechanism [24].

Table 4 Correlation between $\mathrm{IC}_{50}$ values of antioxidant activities and flavonoids and phenolics contents of D. roxburghiana

\begin{tabular}{lcc}
\hline Assays & \multicolumn{2}{c}{ Correlation $\mathbf{R}^{\mathbf{2}}$} \\
\cline { 2 - 3 } & Flavonoids & Phenolics \\
\hline $\mathrm{IC}_{50}$ of DPPH radical scavenging activity & $0.9634^{* *}$ & $0.8830^{*}$ \\
$\mathrm{I} \mathrm{C}_{50}$ of Superoxide radical scavenging activity & $0.9632^{* * *}$ & $0.8588^{* *}$ \\
$\mathrm{I} \mathrm{C}_{50}$ of Phosphomolybdate radical scavenging & $0.8924^{* *}$ & $0.7154^{*}$ \\
activity & & \\
$\mathrm{I} \mathrm{C}_{50}$ of ABTS radical scavenging activity & $0.9458^{* * *}$ & $0.8635^{* *}$ \\
$\mathrm{IC}_{50}$ of $\mathrm{H}_{2} \mathrm{O}_{2}$ radical scavenging activity & 0.3375 & 0.5158 \\
$\mathrm{I} \mathrm{C}_{50}$ of Hydroxyl radical scavenging activity & $0.6608^{*}$ & 0.5883 \\
\hline
\end{tabular}

Values are represented as mean $\pm(n=3), *^{* *}, * * *$ shows level significance $(P<0.05 ; P<0.01, P<0.001)$.
A number of techniques have been followed to evaluate the antioxidant potential of the plants [19] and it was confirmed that plant constituents are more secure than their synthetic counterparts $[38,39]$.

Preliminary phytochemical screening of Dicliptera roxburghiana demonstrated the presence of nearly all active constituents of the plant such as flavonoids, phenolics, tannins, terpenoids, saponins, coumarins and alkaloids; explicate the antioxidant manifestations of the plant because a large number of investigations prove that plants are endowed with antiradical constituents which are powerful scavengers [40]. All these constituents have been shown to exhibit strong antioxidant scavenging activity for the radicals that are involved in the lipid peroxidation [10,41]. These active constituents of plants play a vital role in the treatment of different diseases such as tannins possess anti-inflammatory and anticancer activity [26,42]; flavonoids are antioxidant, anti-inflammatory any anticancer agents [43]; coumarins are antioxidant, maintain blood pressure and inhibit lipid peroxidation [44]; alkaloids possess antileukemic and anticancer activity [45] and saponin are antimicrobial agent and maintain the blood cholesterol level [46].

Extraction yield of different plant derived fractions varied widely; highest methanol extract yield proved that methanol behave as a good solvent for compound extraction where as DRCF yielded small quantity as compared to methanol and other solvents. Determination of flavonoid and phenolics contents determined that DRME and DRCF of D. roxburghiana possess strong antioxidant potential and this may be cumulative effect of both theses constituents. DRME exhibited highest phenolic contents where as contents obtained with DRHF were very low that is in accordance with other reports [47]. Plant flavonoid content determination also justified it to be a strong antioxidant source as such flavonoid rich plants could be a good source of antioxidant 


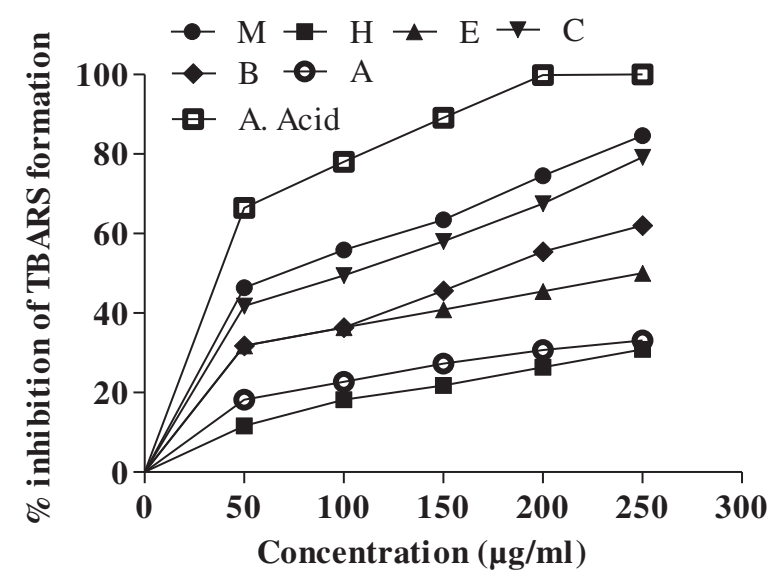

Figure 2 Lipid per oxidation \% inhibition of different fractions of $\boldsymbol{D}$. roxburghiana. M: methanol, H: $n$-hexane, E: ethyl acetate, C: chloroform, B: n-butanol, A: aqueous, G. Acid: gallic acid, A. Acid: ascorbic acid.

to inhibit pathological manifestations caused by free radical that are involved in lipid peroxidation pathways [48]. Our findings suggested that high phenolic and flavonoid contents of the plant are the major contributor to scavenge the free radicals in oxidation pathways.

Antioxidant scavenging capability of the plant has also revealed its strong antioxidant potential in quenching the radicals that cause oxidative trauma in cells. These scavenging activities were concentration dependent. DPPH, a purple colored bleaching solution, is an important source of free radical and is frequently used to measure the electron donating ability of the plant [49]. Extent of color change is proportional to the strength and concentration of antioxidant. In this study DRME, DRCF and DREF exhibited strong DPPH radical quenching activity that is positively correlated with their high phenolics and flavonoid contents. This was due to multifaceted

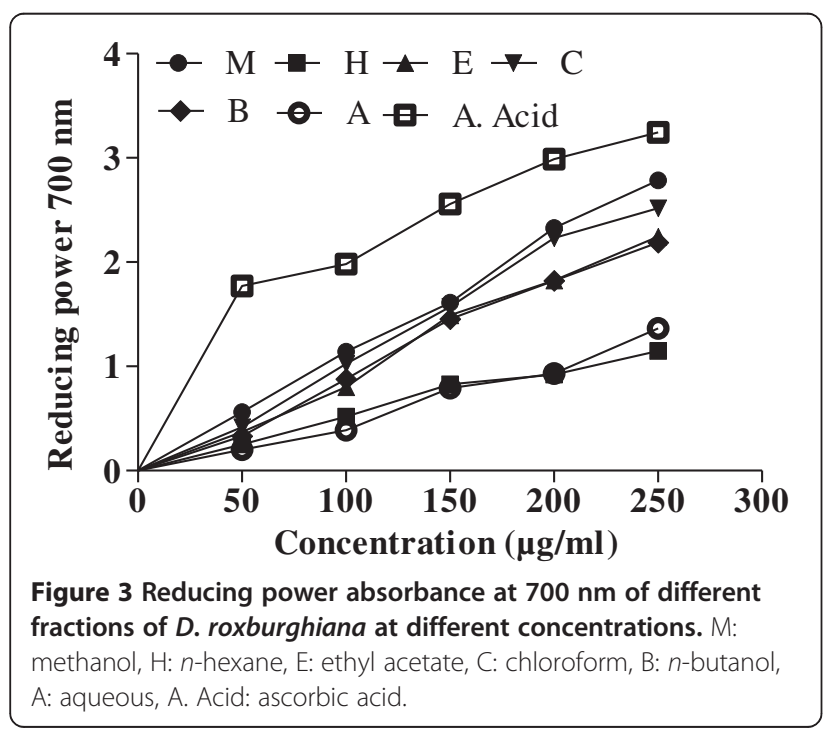

nature of both these constituents that act as health promoting agents; neutralize the DPPH radical by donating hydrogen and protect from probable damage. Presence of apigenin and luteolin flavones in D. roxburghiana might contribute towards the DPPH radical scavenging activity.

Superoxide radical is the important oxygen radical among all reactive oxygen species [50]. Superoxide itself is a weak radical but may cause severe damage to the cell by generating hydroxyl radical and singlet oxygen [51]. Present study suggested that DRME and DRCF had potent scavenging activity against superoxide radical and a strong correlation exist with the flavonoid and phenolic contents of the plant. Present scavenging activity against superoxide radicals might be due to the luteolin because it possesses strong superoxide antiradical capability.

Another important radical called hydroxyl radical also play an important role in pathogenesis. Hydroxyl radical can easily bind to the polyunsaturated fatty acid of the cell membranes phospholipids and cause harmful effect to the cell [27]. Hydroxyl radical can easily bind to every molecule of the cell and cause mutation and carcinogenesis [52]. Hydroxyl radical was produced by the reaction of ferrous ion with 2-deoxyribose result into subsequent formation of malonaldehyde which was inhibited by TBA. Hydroxyl radical activity of the extracts is directly proportional to its antioxidant activity [53]. Structural relationship of apigenin, luteolin and kaempferol demonstrated the antiradical capacity for hydroxyl radicals. Depletion of hydroxyl radicals by the extract and fractions might involve the apigenin, luteolin and kaempferol flavonoids.

Phosphomolybdate is another assay that is performed to assess the overall antioxidant activity of the extract [54]. In the presence of antioxidant sample Mo (VI) 
reduced to Mo $(\mathrm{V})$ with subsequent formation of green colored phosphomolybdenum $\mathrm{V}$ complex exhibiting maximum absorbance at $700 \mathrm{~nm}$. Our findings demonstrate that $D$. roxburghiana has a very good antioxidant potential that was the collective contribution of phenolic and flavonoid components of the plant.

ABTS is a well known reactive radical that can lead to cell damage. In this assay ABTS oxidize to ABTS + chromophore on reaction with potassium persulphate; and reduced by antioxidant sample. Results justify that plant has ABTS radical scavenging activity and proved that plant may be used for the treatment of radical related stress appreciable due to ABTS radical quenching ability [10]. Loss of color in this experiment can be related with the reductive ability of various constituents; apigenin, luteolin and kaempferol in D. roxburghiana.

Hydrogen peroxide is detrimental reactive oxygen radical become toxic and damage the cell when converted into hydroxyl radical that may initiate lipid peroxidation and DNA mutations [55]. Present investigations suggested that all plant extracts were capable of quenching this radical that may be due to their phenolic contents that convert $\mathrm{H}_{2} \mathrm{O}_{2}$ to water.

Reducing power is another assay to measure the overall antioxidant prospective of extract. Plant antioxidants convert the $\mathrm{Fe}+3 /$ ferric cyanide complex to ferrous form by contributing one electron with subsequent turning of yellow color reaction solution to green. Intensity of color change is proportional to the concentration of antioxidant present in test sample. Reducing capability can be monitored spectrophotometrically by increase in absorbance at $700 \mathrm{~nm}$. Previous data reported that reducing ability actually responsible for antioxidant activity by donating hydrogen atom that in turn will break the fee radical chain [56]. Increase in absorbance by all fractions of the plant was an indication of strong antioxidant potential of D. roxburghiana.

Lipid peroxidation is another very important parameter to determine the total antioxidant potential of the plant. Lipids of cellular membranes are more susceptible to oxidative hazards. Lipid peroxidation by free radical results into the production of malonaldehyde (MDA) that reacts with DNA and cause mutation in the form of DNA adducts $[57,58]$. Active components of the D. roxburghiana inhibit the chain reaction to generate lipid peroxides. Present research design proved that all fractions of the plant significantly inhibited the lipid peroxidation that was due to the cumulative contribution of its phenolics and flavonoids contents that play important role in antioxidant manifestations.

\section{Conclusion}

Natural product antioxidants significantly contribute in preventions of pathological consequences caused by free radicals. Furthermore plant derived antioxidant are safer and cheaper than their synthetic counterparts. We concluded from this research design that $D$. roxburghiana possesses strong antioxidant potential that may be due to the contribution of its phenolics and flavonoid contents and it would be advantageous to use the plant antioxidant in therapeutic drugs for the implications of human health.

\section{Competing interest}

The authors declare that they have no competing interests.

\section{Authors' contributions}

BA made significant contribution to acquisition of data, analysis, drafting of the manuscript. MRK has made substantial contribution to conception and design, interpretation of data, drafting and revising the manuscript for intellectual content. NAS and RAK (Khan RA 0000-0003-0453-2090) participated in the design and collection of data and analysis. All authors read and approved the final manuscript.

\section{Acknowledgement}

We are thankful to Higher Education Commission of Pakistan (HEC) for providing support to work out on this research project.

\section{Author details}

'Department of Biochemistry, Faculty of Biological Sciences, Quaid-i-Azam University, Islamabad 45320, Pakistan. ${ }^{2}$ Department of Biotechnology, Faculty of Biological Sciences, University of Science and Technology, Bannu, Khyber Pakhtunkhwa, Pakistan.

Received: 27 November 2012 Accepted: 17 June 2013 Published: 19 June 2013

\section{References}

1. Aiyegoro OA, Okoh Al: Preliminary phytochemical screening and in vitro antioxidant activities of the aqueous extract of Helichrysum longifolium DC. BMC Compl Altern Med 2010, 10:21.

2. Harman D: Aging: phenomena and theories. Ann NY Acad Sci 1998, 854:1-7

3. Khan MR, Rizvi W, Khan GN, Khan RA, Sahreen S: Carbon tetrachlorideinduced nephrotoxicity in rats: Protective role of Digera muricata. J Ethnopharmacol 2009, 122:91-99.

4. Khan RA, Khan MR, Sahreen S: Evaluation of Launea procumbens use in renal disorders: a rat model. J Ethnopharmacol 2010, 128:452-461.

5. Khan RA, Khan MR, Sahreen S, Bokhari J: Prevention of $\mathrm{CCl}_{4}$-induced nephrotoxicity with Sonchus asper in rat. Food Chem Toxicol 2010, 23:1304-1321.

6. Khan RA, Khan MR, Sahreen S, Bokhari J: Antimicrobial and Phytotoxic activity of various fractions of Sonchus asper. Afr J Biotechnol 2010 47:3877-4683.

7. Khan MR, Haroon J, Khan RA, Bokhari J, Rashid U: Prevention of $\mathrm{KBrO}_{3}$ induced cardiotoxicity by Sonchus asper in rat. J Med Plants Res 2011, 5(12):2514-2520.

8. Khan RA, Khan MR, Sahreen S, Jan S, Bokhari J, Rashid U: Phytotoxic characterization of various fractions of Launaea procumbens. Afr J Biotechnol 2011, 10:5377-5380.

9. Cai $Y Z$, Sun $M$, Corke $H$ : Antioxidant activity of betalains from plants of the Amaranthaceae. J Agric Food Chem 2003, 51(8):2288-2294.

10. Sahreen S, Khan MR, Khan RA: Evaluation of antioxidant activities of various solvent extracts of Carissa opaca fruits. Food Chem 2010, 122:1205-1211.

11. Sahreen S, Khan MR, Khan RA: Hepatoprotective effects of methanol extract of Carissa opaca leaves on $\mathrm{CCl}_{4}$-induced damage in rat. BMC Compl Altern Med 2011, 11:48.

12. Bursal E, Koksal E, Gulçin I, Bilsel G, Goren AC: Antioxidant activity and polyphenol content of cherry stem (Cerasus avium L.) determined by LC-MS/MS. Food Res Int 2013, 51(1):66-74.

13. Gulcin I: Antioxidant activity of food constituents: an overview. Arch Toxicol 2012, 86(3):345-391. 
14. Wagner, Warren LH, Derral R, Sohmer SH: Manual of the flowering plants of Hawaii. Revised edition. Bernice P. Bishop Museum special publication: Honolulu; 1999.

15. Bahuguna RP, Jangwan JS, Kaiya T, Sakakibara J: Flavonoids and fatty acids of Dicliptera roxburghiana. Pharm Biol 1987, 25(3):177-178.

16. Qureshi R, Waheed A, Arshad M, Umbreen T: Medico- ethnobotanical inventory of tahsil Chakwal. Pakistan. Pak J Bot 2009, 41(2):529-538.

17. Khan MZ, Khan MA, Hussain M: Medicinal plants used in folk recipes by the inhabitants of himalayan region Poonch Valley Azad Kashmir (Pakistan). J Basic Applied Sci 2012, 8:35-45.

18. Marlesa RJ, Farnsworth NR: Antidiabetic plants and their active constituents. Phytomedicine 1995, 2(2):137-189.

19. Kil HY, Seong ES, Ghimire BK, Chung IM, Kwon SS, Goh EJ, Hoe K, Kim MJ, Lim JD, Lee D, Yu CY: Antioxidant and antimicrobial activities of crude sorghum extract. Food Chem 2009, 115:1234-1239.

20. Bursal E, Gulçin I: Polyphenol contents and in vitro antioxidant activities of lyophilised aqueous extract of kiwifruit (Actinidia deliciosa). Food Res Int 2011, 4(5):1482-1489.

21. Park YS, Jung ST, Kang SG, Heo BK, Arancibia-Avila P, Toledo F, Drzewiecki J, Namiesnik J, Gorinstein S: Antioxidants and proteins in ethylene-treated kiwifruits. Food Chem 2008, 107(2):640-648.

22. Brand-Williams W, Cuvelier ME, Berset C: Use of a free radical method to evaluate antioxidant activity. Lebensm-Wiss U-Technol 1995, 28:25-30.

23. Re R, Pellegrini N, Proteggente A, Pannala A, Yang M, Rice-Evans C: Antioxidant activity applying an improved $A B T S$ radical cation decolorisation assay. Free Rad Bio Med 1999, 26:1231-1237.

24. Umamaheswari M, Chatterjee TK: In vitro antioxidant activities of the fractions of Coccinnia grandis L. leaf extract. Afr J Trad Compl Altern Med 2008, 5(1):61-73.

25. Beauchamp C, Fridovich I: Superoxide dismutase: improved assays and an assay applicable to acrylamide gels. Anal Biochem 1971, 44:276-277.

26. Ruch RJ, Cheng SJ, Klaunig JE: Prevention of cytotoxicity and inhibition of intercellular communication by antioxidant catechins isolated from Chinese green tea. Carcinogen 1989, 10:1003-1008.

27. Halliwell B, Gutteridge JMC: Formation of thiobarbituric acid reactive substances from deoxyribose in the presence of iron salts: the role of superoxide and hydroxyl radicals. FEBS Lett 1981, 128:347-352.

28. Hunter FE, Scott JRA, Hoffsten PE, Gebicki JB, Weinstien J, Schneider A: Studies on mechanism of swelling, lysis and disintegration of isolated liver mitochondria exposed to mixtures of oxidized and reduced glutathione. J Biol Chem 1964, 239(2):614-621.

29. Iqbal M, Sharma SD, Zadeh HR, Hasan N, Abdulla M, Athar M: Glutathione metabolizing enzymes and oxidative stress in ferric nitrilotriacetate (FeNTA) mediated hepatic injury. Redox Rep 1996, 2:385-391.

30. Gulcin I, Topal F, Cakmakc R, Bilsel M, Goren AC, Erdogan U: Pomological features, nutritional quality, polyphenol content analysis and antioxidant properties of domesticated and three wild ecotype forms of raspberries (Rubus idaeus L.). J Food Sci 2011, 76(4):585-593.

31. Farnsworth NR, Euler KL: An alkaloid screening procedure utilizing thinlayer chromatography. Lloyd 1962, 25:186-195.

32. Wall ME, Eddy CR, McClennan ML, Klump ME: Detection and estimation of steroidal sapogenins in plant tissue. Anal Chem 1952, 24:1337-1341.

33. Harborne JB: Phytochemical methods. London: Chapman and Hall, Ltd; 1973:49-118.

34. Trease GE, Evans WC: Pharmacognosy. 11th edition. London: Braillar Tiridel Can Macmillian Publishers; 1989:60-75.

35. Stahl E, Schorn PJ: Thin layer chromatography of hydrophilic medicinal plant extracts, VIII: coumarins, flavones derivatives, hydroxyl acid, tannins, anthracene derivatives and lichens. Physiol Chem 1961, 325:263-274.

36. Sofowara AE: Medicinal plants and traditional medicine in Africa, Volume 2. 2nd edition. Ibadan, Nigeria: Spectrum books Ltd; 1993:289.

37. Katoch A, Batta B, Kumar, Sharma PC: Screening of Murraya koenigii (curry) and Camellia sinensis (tea) leaves for antimicrobial activity against strains of Staphylococcus aureus, Pseudomonas aeroginosa, and Candida species and their phytochemical analysis. IJPSR 2013, 4(2):859-865.

38. Vongtau HO, Abbah J, Chindo BA, Mosugu O, Salawu AO, Kwanashie HO, Gamaniel KS: Central inhibitory effects of the methanol extract of Neorautanenia mitis root in rats and mice. J Pharm Biol 2005, 43:113-120.
39. Oluyemi KA, Okwuonu UC, Baxter DG, Oyesola TO: Toxic effects of methanolic extract of Aspilia africana leaf on the estrous cycle and uterine tissues of Wistar rats. Int J Morphol 2007, 25:609-614.

40. Zheng W, Wang SY: Antioxidant activity and phenolic compounds in selected herbs. J Agric Food Chem 2001, 49(11):5165-5170.

41. Etuk EU, Agaie BM, Ladan MJ, Garba I: The modulatory effect of Cochlospermum tinctorium a rich aqueous root extract on liver damage induced by carbon tetrachloride in rats. Afr J Pharm Pharmacol 2009, 3(4):151-157.

42. Motar MLR, Thomas G, Barbosa Fillo JM: Effects of Anacardium occidentale stem bark extract on in vivo inflammatory models. J Ethnopharmacol 1985, 95(2):139-142.

43. Ogunleye DS, Ibitoye SF: Studies of antimicrobial activity and chemical constituents of Ximenia americana. Trop J Pharm Res 2003, 2(2):239-241.

44. Thuong PT, Hung TM, Ngoc TM, Ha do T, Min BS, Kwack SJ, Kang TS, Choi JS, Bae K: Antioxidant activities of coumarins from Korean medicinal plants and their structure-activity relationships. Phytother Res 2010, 24(1):101-106.

45. Decorti RC, Creacy WA: In the Cantharadus Alkaloids. In Macel Dekker Edited by Taylor W, Fanworths NR. New York: Taylor W1 and Fanworths NR Publishers; 1975:237-278

46. Cheeke PP: Surprising benefits of desert plants. In The Linus Paulin Institute. Aregon University; 2005:38.

47. Ao C, Li A, Elzaawely AA, Xuan DT, Twata S: Evaluation of antioxidant and antibacterial activities of Ficus microcarpa L. fill extract. Food Contrl 2008 19:940-948.

48. Sharififar F, Dehghn-Nudeh G, Mirtajaldini M: Major flavonoids with antioxidant activity from Teucrium polium L. Food Chem 2009, 112:885-888

49. Nunes PX, Silva SF, Guedes RJ, Almeida S: Biological oxidations and antioxidant activity of natural products. Phytochemicals as nutraceuticals Global Approaches to Their Role in Nutrition and: Health; 2012.

50. Alves CQ, David JM, David JP, Bahia MV, Aguiar RM: Methods for determination of in vitro antioxidant activity for extracts and organic compounds. Química Nova 2010, 33:2202-2210.

51. Meyer AS, Isaksen A: Application of enzymes as food antioxidants. Trends Food Sci Tech 1995, 6:300-304.

52. Babu BH, Shylesh BS, Padikkala J: Antioxidant and hepatoprotective effect of Alanthus icicifocus. Fitoterapia 2001, 72:272-277.

53. Gulcin I, Berashvili D, Gepdiremen A: Antiradical and antioxidant activity of total anthocyanins from Perilla pankinensis decne. J Ethnopharmacol 2005, 101:287-293.

54. Khan RA, Khan MR, Sahreen S: Assessment of flavonoids contents and in vitro antioxidant activity of Launaea procumbens. Chem Central J 2012, 6:43-S.

55. Gulcin I, Oktay M, Kirecci E, Kufrevioglu Ol: Screening of antioxidant and antimicrobial activities of anise (Pimpinella anisum $\mathrm{L}$ ) seed extracts. Food Chem 2003, 83:371-382.

56. Gordon $\mathrm{MH}$ : The mechanism of antioxidant action in vitro. In Food antioxidants. Edited by Hudson BJ. London: Elsevier Applied Science; 1990:1-18

57. Marnett JL: Oxyradicals and DNA damage. Carcinogenesis 2000, 21:361-370.

58. Dedon PC, Plastaras JP, Rouzer CA, Marnett $\sqcup$ : Indirect mutagenesis by oxidative DNA damages: Formation of the pyrimidopurinone adduct of deoxyguanosine by base propenal. Proc Nat Aca Sci USA 1998, 95:11113-11116.

doi:10.1186/1472-6882-13-140

Cite this article as: Ahmad et al:: In vitro antioxidant potential of

dicliptera roxburghiana. BMC Complementary and Alternative Medicine 2013 13:140. 